Materiales de Construcción

Vol. 69, Issue 335, July-September 2019, e191

ISSN-L: $0465-2746$

https://doi.org/10.3989/mc.2019.06618

\title{
Alkali-activated binary concrete based on a natural pozzolan: physical, mechanical and microstructural characterization
}

\author{
R. Robayo-Salazar ${ }^{\mathrm{a}}$, R. Mejía de Gutiérrez ${ }^{\mathrm{a}} \bowtie$, F. Puertas ${ }^{\mathrm{b}}$ \\ a. Composites Materials Group (CENM), School of Materials Engineering, Universidad del Valle, (Cali, Colombia) \\ b. Eduardo Torroja Institute for Construction Science (IETcc-CSIC), (Madrid, Spain) \\ $\bowtie$ : ruby.mejia@correounivalle.edu.co
}

\begin{abstract}
This article presents the physical, mechanical and microstructural characterization of an alkaliactivated binary concrete $(\mathrm{AABC})$ based on a natural pozzolan $(\mathrm{NP})$ of volcanic origin $(70 \%)$ and granulated blast furnace slag (GBFS) $(30 \%)$ cured at room temperature $\left(25^{\circ} \mathrm{C}\right)$. A solution based on the combination of $\mathrm{NaOH}$ and waterglass $\left(\mathrm{Na}_{2} \mathrm{SiO}_{3} \cdot 5 \mathrm{H}_{2} \mathrm{O}\right)$ was employed as an alkaline activator. The concrete design was obtained using a modified version of the "absolute volume" method (ACI 211.1). The performance of the AABC was similar and even superior to that of the reference concrete (OPC); e.g., it exhibited a compressive strength of up to $43.4 \mathrm{MPa}$ at 360 days. These results demonstrate that the NP has potential for use in the industrial-scale production of these types of materials in the foreseeable future.
\end{abstract}

KEYWORDS: Alkali-activated concrete; Binary concrete; Natural volcanic pozzolan; Granulated blast furnace slag; Mechanical and physical properties

Citation/Citar como: Robayo-Salazar, R.; Mejía de Gutiérrez, R.; Puertas, F. (2019) Alkali-activated binary concrete based on a natural pozzolan: physical, mechanical and microstructural characterization. Mater. Construcc. 69 [335], e191 https://doi.org/10.3989/mc.2019.06618

RESUMEN: Hormigón binario álcali-activado basado en puzolana natural volcánica: Caracterización física, mecánica y microestructural. Este artículo presenta la caracterización física, mecánica y microestructural de un hormigón binario (AABC) basado en la activación alcalina de una puzolana natural (NP) de origen volcánico $(70 \%)$ y una escoria siderúrgica de alto horno (GBFS) $(30 \%)$, curado a temperatura ambiente $\left(25^{\circ} \mathrm{C}\right)$. Una solución basada en la combinación de $\mathrm{NaOH}$ y waterglass $\left(\mathrm{Na}_{2} \mathrm{SiO}_{3} \cdot 5 \mathrm{H}_{2} \mathrm{O}\right)$ fue usada como activador alcalino. El diseño de los hormigones se realizó con el método de "volumen absoluto" definido por ACI 211.1 con algunas modificaciones. El desempeño de AABC fue similar e incluso superior al hormigón de referencia (OPC), reportando niveles de resistencia a la compresión de hasta $43.4 \mathrm{MPa}$ a los 360 días. Estos resultados demuestran que NP puede ser utilizada en la producción a escala industrial de este tipo de materiales en un futuro predecible.

PALABRAS CLAVE: Hormigón activado alcalinamente; Hormigón binario; Puzolana natural volcánica; Escoria granulada de horno alto; Propiedades físicas y mecánicas

ORCID ID: R. Robayo-Salazar (https://orcid.org/0000-0003-1687-2885); R. Mejía de Gutiérrez (https://orcid. org/0000-0002-5404-2738); F. Puertas (https://orcid.org/0000-0002-4215-0184)

Copyright: (C) 2019 CSIC. This is an open-access article distributed under the terms of the Creative Commons Attribution 4.0 International (CC BY 4.0) License. 


\section{INTRODUCTION}

From an environmental perspective, alkali-activated materials (AAMs), which are sometimes also called geopolymers (1), are considered a sustainable alternative to Portland cement (OPC) in some applications in the construction industry because their $\mathrm{CO}_{2}$ footprint is lower than that of OPC production (2). However, these materials (AAMs) are not expected to be utilized in all OPC applications due to the limited availability of some of the raw materials and the requirement for some rigorous control protocols during their manufacturing and curing (3). However, AAMs are currently considered key materials for the future sustainability of this industry (4) and are included in some standards, such as ASTM 1157 (EUA), NTC 121 (Colombia), PAS 8820 (United Kingdom), SIA 2049 (Switzerland), GB/T 29423 (China), and other prescriptive standards (Ukraine, Russia, Australia). Moreover, ASTM and RILEM (TC 244-AAM) technical committees (5) have focused their efforts on establishing regulations and standards for controlling and promoting their use in the construction industry worldwide.

Since these materials were first fabricated, they have been shown to exhibit high mechanical performance and chemical resistance, making their use attractive (6-8). However, some barriers to exploiting these advances on an industrial scale currently exist (9). It is believed that the lack of studies focused on using readily available aluminosilicates (precursors) is the main barrier. Therefore, some authors (3) argue that studies should focus on the use of resources such as natural pozzolans (NPs) of volcanic origin, which comprise $0.84 \%$ of the world's soils (124 million hectares) (10). Indeed, volcanic soils represent an important resource for countries such as Iran, Cameroon, Japan, China, Saudi Arabia, Turkey, Jordan, Italy, Greece, the United States of America, Mexico, Chile, Ecuador and Colombia (11), where their deposits are generally concentrated in areas of high demographic and economic growth. For example, NPs constitute $11 \%$ of Colombia's territory and are concentrated in the central and southwest zones of the country. In Chile, they represent $50 \%$ of the total arable land of the country and are concentrated in the metropolitan regions, while they represent $18 \%$ of Japan's territory $(12,13)$. Moreover, Southern Europe is the original source of pozzolans.

Little information about the use of NPs in the field of alkaline activation has been published in the literature (14). However, Allahverdi et al. $(15,16)$, Kani et al. (17-21), Lemougna et al. (22-25), Bondar et al. (26-34), Djobo et al. (35-40) and Tchakoute et al. (41-44) reported promising results demonstrating their potential as a geopolymeric precursor. These researchers state that NPs generally have a certain degree of amorphous content $(\leq 30 \%)$ that makes them reactive in the presence of strongly alkaline solutions. However, due to their predominantly semi-crystalline nature and low $\mathrm{CaO}$ and reactive $\mathrm{Al}_{2} \mathrm{O}_{3}$ contents, hydrothermal curing treatments $\left(40-90^{\circ} \mathrm{C}\right)$ are commonly employed to improve the mechanical performance of early age AAMs. Such treatments undoubtedly limit the use of these materials in some applications. Therefore, it has been demonstrated that modifiers or secondary sources of calcium $(\mathrm{CaO})$ and reactive $\mathrm{Al}_{2} \mathrm{O}_{3}$ can be incorporated into these binders to render the thermal curing process unnecessary. Indeed, adding a small amount $(\leq 30 \%)$ of granulated blast furnace slag (GBFS) to NPs to obtain alkali-activated binary cements allows these materials to harden at room temperature $\left(25^{\circ} \mathrm{C}\right)(16,21,45-48)$, thus enabling their use in "on-site" applications. Incorporating GBFS into NPs is advantageous because its dissolution during the alkaline activation process produces many $\mathrm{Ca}^{2+}$ ions that participate in the formation of calcium silicate hydrate (C-S-H) and calcium aluminosilicate hydrate (C-A-S-H) gels (49-51).

It should be noted that the above-mentioned results are not validated at the concrete level. Moreover, most of the published studies have been focused on determining the properties of pastes and mortars based on NPs. Therefore, studies based on concrete are very limited. Bondar et al. $(33,34)$ reported that concretes with compressive strengths of close to $25 \mathrm{MPa}$ after 28 days of curing $\left(20 \pm 2^{\circ} \mathrm{C}\right)$ were obtained from Iranian pozzolans activated with $\mathrm{KOH}$ and $\mathrm{Na}_{2} \mathrm{SiO}_{3}$; however, compressive strengths of up to $50 \mathrm{MPa}$ were observed after curing at $60^{\circ} \mathrm{C}$. Haddad and Alshbuol (52) reported compressive strengths of 8.9-24.1 MPa for concrete obtained by curing a Jordanian NP activated with $\mathrm{NaOH}$ and $\mathrm{Na}_{2} \mathrm{SiO}_{3}$ under laboratory conditions for 28 days. They also found that thermally treating the material at $80^{\circ} \mathrm{C}$ for 24 hours resulted in a compressive strength of up to $30.8 \mathrm{MPa}$ at 28 days. In his doctoral thesis, Najimi (53) studied the properties of concretes based on alkali-activated NP/slag using combinations of 70/30, 50/50 and 30/70; from the results, the author concluded that $50 / 50$ is the optimum composition because the resultant concrete featured the highest compressive strength, i.e., 20 to $45 \mathrm{MPa}$ at a curing age of 28 days, depending on the ratio of hydroxide to sodium silicate used in the mixture.

In a previous study (47), the feasibility of obtaining a binary binder (paste) using a 70\% NP:30\% GBFS mixture activated with a $\mathrm{NaOH}$ and waterglass $\left(\mathrm{Na}_{2} \mathrm{SiO}_{3} \cdot 5 \mathrm{H}_{2} \mathrm{O}\right)$ solution was explored. In that study, the alkaline binder was classified as a GU (general use) and LH (low heat of reaction) cement type based on the NTC 121 standard (equivalent to ASTM 1157 (54)). The objective of the present study is to obtain an alkali-activated binary concrete $(\mathrm{A} A B C)$ using the same binary binder and 
determine its physical (water absorption, density and porosity), mechanical (compressive, flexural, and splitting tensile strengths and modulus of elasticity) and microstructural (characterized by scanning electron microscopy and energy-dispersive X-ray spectroscopy (SEM-EDS)) properties in order to demonstrate the feasibility of using this material as an alternative to OPC concrete in countries rich in volcanic soils, such as Colombia.

\section{MATERIALS AND METHODOLOGY}

\subsection{Materials}

A mixture of $70 \%$ natural volcanic pozzolan (NP) of Colombian origin and 30\% granulated blast furnace slag (GBFS) was used as the AABC precursor. The chemical compositions of these materials were determined by X-ray fluorescence (XRF) and are listed in Table 1. The high $\mathrm{SiO}_{2} / \mathrm{Al}_{2} \mathrm{O}_{3}$ molar ratio (6.79) and low alkaline content $\left(\mathrm{CaO}, \mathrm{Na}_{2} \mathrm{O}\right.$ and $\mathrm{K}_{2} \mathrm{O}$ ) of the NP are notable. The GBFS has a $\mathrm{SiO}_{2} / \mathrm{Al}_{2} \mathrm{O}_{3}$ molar ratio of 4.93 and a $\mathrm{CaO}$ content of $40.3 \%$. The NP and GBFS mean particle sizes were determined to be 20.63 and $26.44 \mu \mathrm{m}$, respectively, by laser granulometry. Adding GBFS to the mixture as a calcium source enables the AABC to be cured at room temperature $\left(25^{\circ} \mathrm{C}\right)$. The alkaline activator consisted of a dissolution of industrial grade sodium hydroxide $(\mathrm{NaOH})$ and commercial sodium silicate or waterglass $\left(\mathrm{Na}_{2} \mathrm{SiO}_{3} \cdot 5 \mathrm{H}_{2} \mathrm{O}\right)$ $\left(\mathrm{SiO}_{2}=32.09 \%, \mathrm{Na}_{2} \mathrm{O}=11.92 \%, \mathrm{H}_{2} \mathrm{O}=55.99 \%\right)$ $\left(\mathrm{SiO}_{2} / \mathrm{Na}_{2} \mathrm{O}\right.$ modulus $\left.=1.1\right)$. Ordinary Portland cement (OPC) (GU type-NTC 121, equivalent to ASTM C1157 (54)) was used to produce the reference concrete. Its chemical composition is included in Table 1. It should be noted that in a previous study (47), the binder obtained by the alkaline activation of the $70 \% \mathrm{NP}-30 \%$ GBFS mixture was classified as a GU and LH type cement based on its performance and the NTC 121 standard.

The natural aggregates used to produce the concretes (AABC and OPC) were crushed gravel with a maximum particle size of $12.7 \mathrm{~mm}$ and siliceous sand extracted from a local river with a fineness modulus of 1.85 . These aggregates meet the specifications for use in concrete mixtures according to ASTM standards. Their main properties are listed in Table 2, and their granulometric distributions are shown in Figure 1.

\subsection{Mixture design and specimen preparation}

The design specifications for the AABC mixtures were a minimum compressive strength of $21 \mathrm{MPa}$ at 28 days and a slump of greater than $18 \mathrm{~cm}$ (fluid consistency). The amount of the $70 \% \mathrm{NP}-30 \% \mathrm{GBFS}$ precursor and the $\mathrm{L} / \mathrm{S}$ ratio required to meet these design specifications were $400 \mathrm{~kg} / \mathrm{m}^{3}$ and 0.35 , respectively. The proportions of the mixture components were determined using a modified version of the "absolute volume method" in the ACI 211.1 (55) guidelines for OPC concretes. In this method, the absolute volumes displaced by all the mixture components and thus the densities of each component, including the alkaline activator (sodium hydroxide,

TABLE 1. Chemical compositions of the raw materials ( $\%$ by weight of oxides).

\begin{tabular}{lccccccccccc}
\hline Material & $\mathbf{S i O}_{2}$ & $\mathbf{A l}_{2} \mathbf{O}_{3}$ & $\mathbf{F e}_{2} \mathbf{O}_{3}$ & $\mathbf{C a O}$ & $\mathbf{N a}_{2} \mathbf{O}$ & $\mathbf{M g O}$ & $\mathbf{K}_{2} \mathbf{O}$ & $\mathbf{S O}_{3}$ & $\mathbf{L O I}^{*}$ & Other & $\mathbf{S i O}_{2} / \mathbf{A l}_{2} \mathbf{O}_{3}$ molar ratio \\
\hline NP & 61.99 & 15.52 & 7.33 & 5.19 & 4.07 & 2.49 & 1.59 & -- & 0.48 & 1.34 & 6.79 \\
GBFS & 37.74 & 15.69 & 1.85 & 40.30 & 0.20 & 1.30 & 0.40 & --- & -- & 2.52 & 4.09 \\
OPC & 17.99 & 3.88 & 4.76 & 62.28 & 0.23 & 1.71 & 0.32 & 4.03 & 4.14 & 0.66 & --- \\
\hline
\end{tabular}

(*LOI: loss on ignition)

TABLE 2. Fine and coarse aggregate properties.

\begin{tabular}{|c|c|c|c|c|}
\hline \multirow[b]{2}{*}{ Property } & \multicolumn{2}{|c|}{ Sand } & \multicolumn{2}{|c|}{ Gravel } \\
\hline & Standard & Result & Standard & Result \\
\hline Apparent relative density $\left(\mathrm{kg} / \mathrm{m}^{3}\right)$ & ASTM C128 & 2570 & ASTM C127 & 2520 \\
\hline Absorption $(\%)$ & ASTM C128 & 2.54 & ASTM C127 & 3.57 \\
\hline Loose unit weight $\left(\mathrm{kg} / \mathrm{m}^{3}\right)$ & ASTM C29 & 1630 & ASTM C29 & 1470 \\
\hline Compact unit weight $\left(\mathrm{kg} / \mathrm{m}^{3}\right)$ & ASTM C29 & 1740 & ASTM C29 & 1590 \\
\hline Fineness modulus & ASTM C136 & 1.85 & ASTM C136 & N.A. \\
\hline Nominal maximum size (mm) & ASTM C136 & N.A & ASTM C136 & 9.52 \\
\hline Maximum size (mm) & ASTM C136 & N.A & ASTM C136 & 12.7 \\
\hline
\end{tabular}

(N.A. = not applicable) 
waterglass and mixing water solution), must be known. The volume of the naturally trapped air was not considered. The optimal granulometric combination of the aggregates ( $45 \%$ sand- $55 \%$ gravel) was determined by the "Fuller-Thompson" method (56). The design specifications and methodology used to determine the proportions for the OPC concrete were the same as those used for the AABC to ensure that the results are comparable. Table 3 shows the dry weights of the components used to prepare $1 \mathrm{~m}^{3}$ of both types of concrete (amount of cement (OPC) or precursor (NP-GBFS): $400 \mathrm{~kg} / \mathrm{m}^{3}$ ). In addition, the binder content (NP-GBFS) used in the AABC preparation was varied between 300 and $600 \mathrm{~kg} /$ $\mathrm{m}^{3}$, and the compressive strength, water absorption, density and porosity of the concrete samples were measured. The proportions of these mixtures (Table 4) were determined following the same procedure (absolute volume method) using a constant $\mathrm{L} / \mathrm{S}$ ratio $(0.35)$.

The concretes were prepared in a CreteAngle horizontal mixer with mixing times of 8 and 15 minutes for the $\mathrm{OPC}$ concrete and $\mathrm{AABC}$, respectively. The slump $(\geq 18 \mathrm{~cm})$ of the mixtures was measured according to the ASTM C143

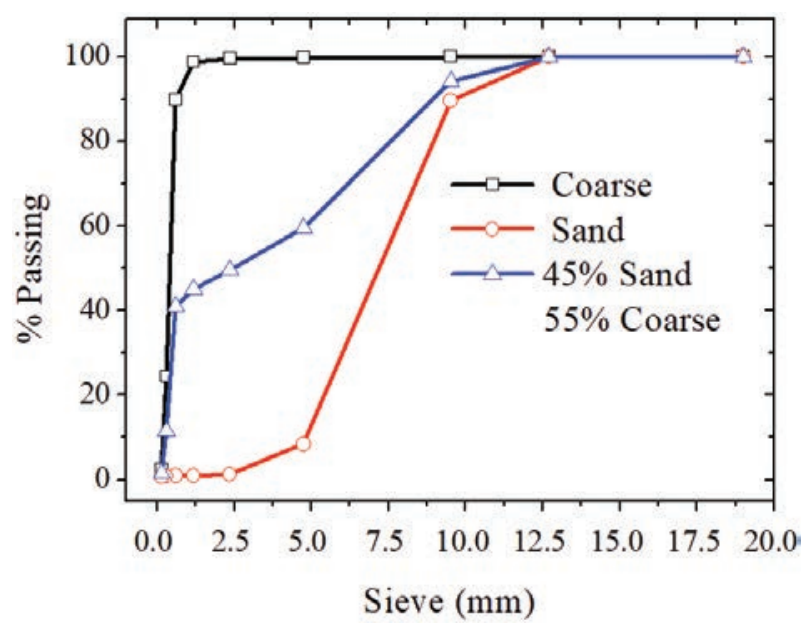

Figure 1. Granulometric distributions of the aggregates. standard (57) (Figure 2). The AABC exhibits notably high fluidity and resistance to segregation (cohesiveness). The mixtures were cast and vibrated for 30 seconds on an electric vibrating table to remove trapped air. The moulds were covered for 24 hours with a polymer film, and then the specimens were removed from the mould. The $\mathrm{AABC}$ specimens were cured at room temperature $\left( \pm 25^{\circ} \mathrm{C}\right)$ and a relative humidity of greater than $80 \%$ until the test age was reached. The OPC was cured in water (immersion). The final distribution of the aggregates and the homogeneity of the mixtures in the hardened state were determined by examining a longitudinal cut of the cylindrical specimen (Figure 3).

TABLE 4. Amounts of the components used to prepare $1 \mathrm{~m}^{3}$ of the concretes with binder contents of $300-600 \mathrm{~kg} / \mathrm{m}^{3}$.

\begin{tabular}{lrcr}
\hline & \multicolumn{3}{c}{ Dry weight $(\mathbf{k g})$} \\
\cline { 2 - 4 } Material & \multicolumn{3}{c}{ Binder content $\left(\mathbf{k g} / \mathbf{m}^{3}\right)$} \\
\cline { 2 - 4 } NP & 210.0 & $\mathbf{4 5 0}$ & $\mathbf{6 0 0}$ \\
GBFS & 90.0 & 135.0 & 420.0 \\
Activator & 186.6 & 280 & 180.0 \\
Gravel & 1049.8 & 874.2 & 373.3 \\
Sand & 858.9 & 715.2 & 571.5 \\
Total volume $\left(\mathrm{m}^{3}\right)$ & 1.0 & 1.0 & 1.0 \\
\hline
\end{tabular}

(Activator: sodium hydroxide + waterglass + mixing water) a)

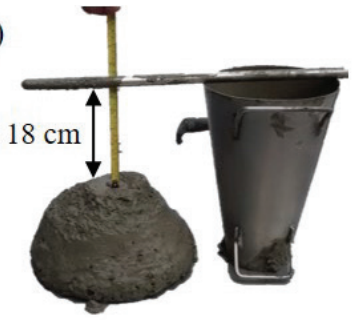

b)

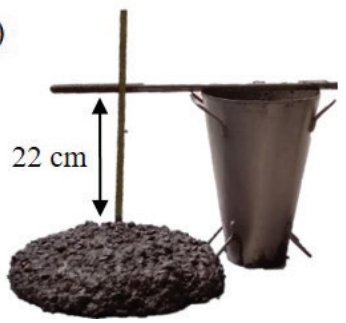

Figure 2. Slump test of the mixtures $\left(400 \mathrm{~kg} / \mathrm{m}^{3}\right)$ : a) OPC $($ slump $=18 \mathrm{~cm})$ and $\mathrm{b})$ AABC $($ slump $=22 \mathrm{~cm})$.

TABLE 3. Amounts of the components used to prepare $1 \mathrm{~m}^{3}$ of the concretes $\left(400 \mathrm{~kg} / \mathrm{m}^{3}\right.$ binder).

\begin{tabular}{|c|c|c|c|c|c|c|c|}
\hline \multicolumn{4}{|c|}{ AABC } & \multicolumn{4}{|c|}{ OPC } \\
\hline Material & Dry weight (kg) & Density $\left(\mathrm{kg} / \mathrm{m}^{3}\right)$ & Volume $\left(\mathrm{m}^{3}\right)$ & Material & Dry weight (kg) & Density $\left(\mathrm{kg} / \mathrm{m}^{3}\right)$ & Volume $\left(\mathrm{m}^{3}\right)$ \\
\hline NP & 280.0 & 2780 & 0.101 & OPC & 400.0 & 3100 & 0.129 \\
\hline GBFS & 120.0 & 2918 & 0.041 & & & & \\
\hline Activator & 248.9 & 1293 & 0.193 & Water & 200.0 & 1000 & 0.200 \\
\hline Gravel & 930.9 & 2520 & 0.369 & Gravel & 940.0 & 2520 & 0.373 \\
\hline Sand & 761.6 & 2570 & 0.296 & Sand & 769.1 & 2570 & 0.299 \\
\hline Total & 2341.4 & --- & 1.0 & Total & 2309.1 & --- & 1.0 \\
\hline
\end{tabular}

(Activator: sodium hydroxide + waterglass + mixing water) 


\subsection{Instrumental techniques and tests}

To analyse the raw and concrete materials, the following instruments and test methods were used:

- XRF was performed using a Phillips PANalytical MagiX Pro PW 2440 spectrometer that has a maximum power of $4 \mathrm{~kW}$ and that was equipped with a rhodium tube.

- Laser granulometry was performed using a Malvern Instruments Mastersizer 2000 particle size analyser and a Hydro 2000MU dispersion unit with distilled water as the dispersing medium.

- SEM was performed using a JEOL JSM6490LV microscope with an accelerating voltage of $20 \mathrm{kV}$. The specimens were examined in low vacuum mode. An Oxford Instruments Link ISIS X-ray spectrometer (EDS) was coupled to the microscope. The samples consisted of approximately $1 \mathrm{~cm}^{3}$ pieces extracted from the AABC (28 days of curing) by precision cutting. The samples were encapsulated in epoxy resin, and the observation surface was polished.

- The pore size distribution of the pulps was determined by the mercury porosimetry technique using a Micromeritics AutoPore IV 9500 Series instrument. The samples consisted of approximately $1 \mathrm{~cm}^{3}$ pieces extracted from the $\mathrm{AABC}$ ( 28 days of curing) by precision cutting.

- The compressive strength was evaluated according to the ASTM C39 standard (58) using
$\mathrm{AABC}$

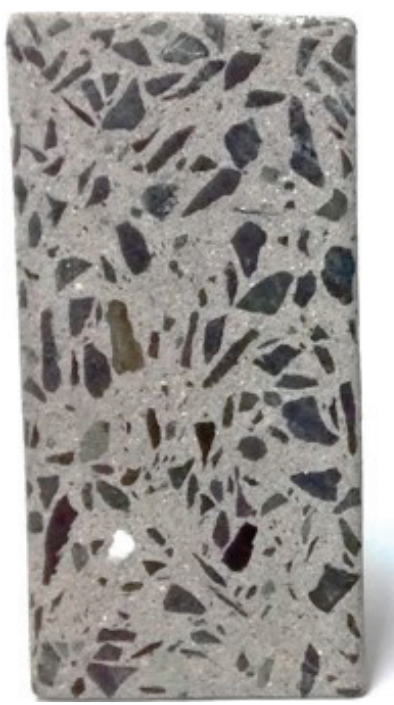

$\mathrm{OPC}$

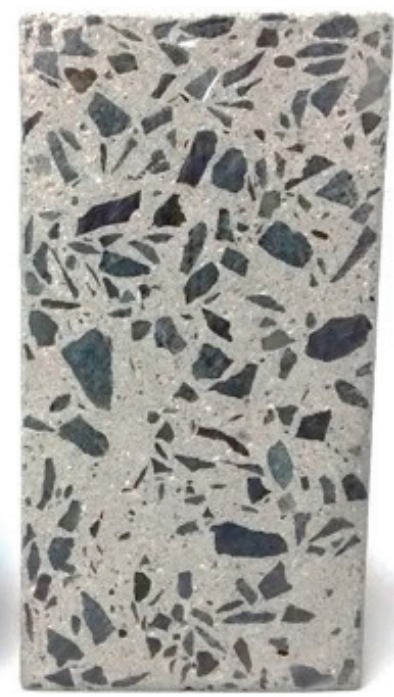

FIGURE 3. Final distribution of the aggregates and homogeneity of the AABC and OPC concrete mixtures $\left(400 \mathrm{~kg} / \mathrm{m}^{3}\right)$ in their hardened state. The colours and appearances of the two concretes are similar, which is commercially advantageous.
$50.8 \mathrm{~mm}$-diameter cylinders in a hydraulic press (ELE International) with a $1000 \mathrm{kN}$ capacity. The modulus of elasticity in compression was determined according to the ASTM C469 standard (59) using $76.2 \mathrm{~mm}$-diameter cylinders.

- The indirect tensile strength was evaluated according to the ASTM C496 standard (60) using $76.2 \mathrm{~mm}$-diameter cylinders.

- The flexural strength (also known as the modulus of rupture) was determined by a 3-point flexural test performed according to the ASTM C293 standard (61) using a $75 \times 75 \times 300 \mathrm{~mm}^{3}$ beam. The test was conducted on an Instron 3369 universal testing machine with a $50 \mathrm{kN}$ capacity at a loading speed of $1 \mathrm{~mm} / \mathrm{min}$.

- The water absorption, density and porosity of the concrete were determined according to the ASTM C642 standard (62) using $76.2 \mathrm{~mm}$ diameter cylinders.

The data reported for all physical and mechanical tests are the averages of three test cylinders.

\section{RESULTS AND DISCUSSION}

\subsection{Mechanical characterization}

Figure 4 compares the evolution of the compressive strengths of the AABC and OPC concretes. In general, both concretes met the design strength specifications $\left(f^{\prime} c=21 \mathrm{MPa}\right)$ and exhibited equivalent performance $(\sim 23 \mathrm{MPa})$ after 28 days of curing. It should be noted that the strength of the $\mathrm{AABC}$ increased more than that of the OPC concrete at longer curing times, reaching a value of up to $33.2 \mathrm{MPa}$ at 360 days, which was $10.8 \%$ higher than that reached by the OPC concrete. However, its

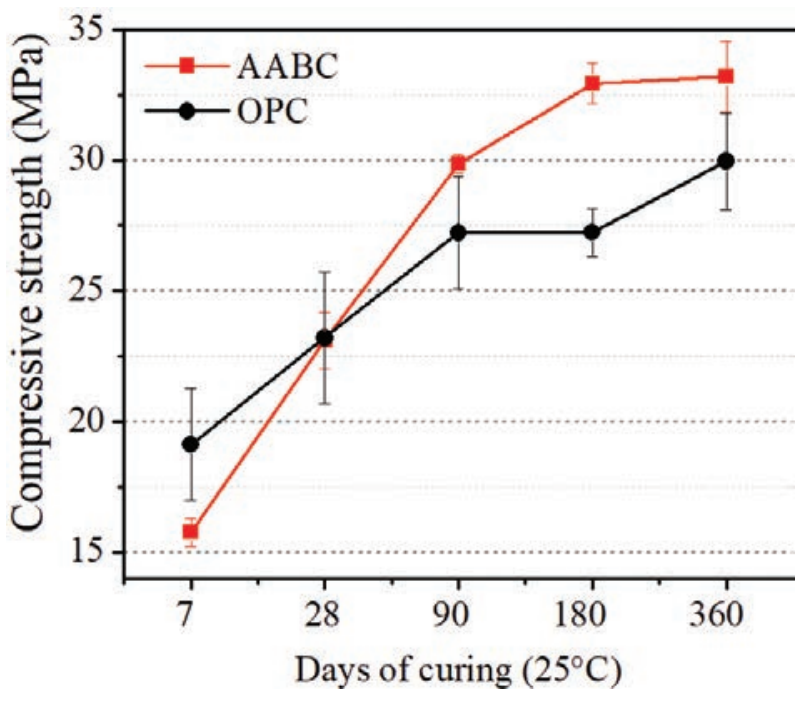

FIGURE 4. Evolution of the compressive strengths (ASTM $\mathrm{C} 39(58))$ of the AABC and OPC concrete $\left(400 \mathrm{~kg} / \mathrm{m}^{3}\right)$. 
early age compressive strength (7 days) was $17.5 \%$ lower than that of the reference concrete (OPC). This behaviour was also observed at the mortar level in a previous study (47) and is attributed to differences in the nature and kinetics of the reactions that give rise to the cementitious gels. In contrast, Ibrahim et al. (63) demonstrated the possibility of reaching $75 \%$ of the final strength ( 28 days) in the first 3 days of curing using an NP-based $\left(400 \mathrm{~kg} / \mathrm{m}^{3}\right)$ concrete activated with $\mathrm{NaOH}$ and waterglass but cured at $60^{\circ} \mathrm{C}$. The mechanical performance of the $\mathrm{AABC}\left(25^{\circ} \mathrm{C}\right)$ (Figure 4) is similar to those reported by Bondar et al. (33) for a concrete based on an Iranian $\mathrm{NP}$ cured at $20 \pm 2^{\circ} \mathrm{C}(\sim 25 \mathrm{MPa}$ at 28 days $)$ (NP content of $344-417 \mathrm{~kg} / \mathrm{m}^{3} ; \mathrm{KOH}+\mathrm{Na}_{2} \mathrm{SiO}_{3}$ alkaline activator) (34). Bondar et al. (33) also reported a compressive strength of up to $50 \mathrm{MPa}$ after 28 days when this same concrete was cured at $60^{\circ} \mathrm{C}$. In another study, Haddad and Alshbuol (52) measured compressive strengths of 8.9-24.1 MPa for a Jordanian NP-based $\left(410 \mathrm{~kg} / \mathrm{m}^{3}\right)$ concrete activated with $\mathrm{NaOH}$ and $\mathrm{Na}_{2} \mathrm{SiO}_{3}$ after 28 days of curing under laboratory conditions (in air). Similarly, the authors also emphasized that thermally treating the concrete at $80^{\circ} \mathrm{C}$ for 24 hours resulted in performance of up to $30.8 \mathrm{MPa}$ at 28 days.

Some authors $(33,52,63)$ clearly support the practice of heat-treating NP-based concretes to increase their early age mechanical performance, although it is believed that doing so limits their real application. Therefore, in this study, the mixtures were designed to achieve an acceptable early age mechanical performance using a curing temperature of $25^{\circ} \mathrm{C}$. Figure 5 shows the effect of the binder (NP-GBFS) content $\left(\mathrm{kg} / \mathrm{m}^{3}\right)$ on the compressive strength of the $\mathrm{AABC}$. In general, the performance

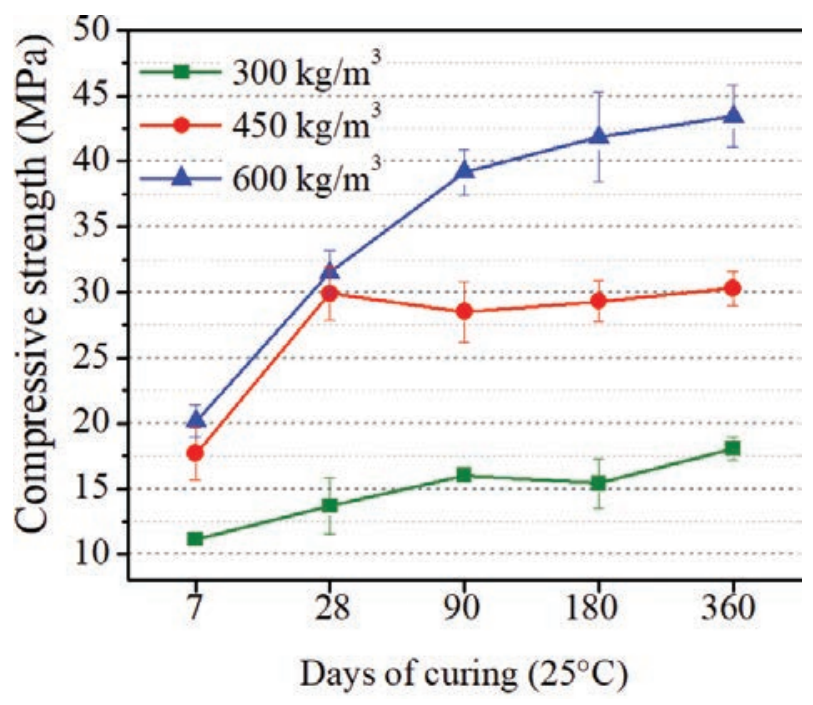

FIGURE 5. Effects of the binder content $\left(300-600 \mathrm{~kg} / \mathrm{m}^{3}\right.$ NP-GBFS) and curing time on the compressive strength (ASTM C39 (58)) of the AABC. of the $\mathrm{AABC}$ increased with increasing binder content $\left(300<450<600 \mathrm{~kg} / \mathrm{m}^{3}\right)$. This behaviour is due to the increase in the phase responsible for the mechanical strength, i.e., the binder, and the decrease in the volume of aggregates in the mixture. When the binder content was $600 \mathrm{~kg} / \mathrm{m}^{3}$, compressive strengths of up to 31.5 and $43.4 \mathrm{MPa}$ were measured after 28 and 360 days of curing, respectively. Because of this behaviour, the curing time (at $25^{\circ} \mathrm{C}$ ) required to achieve a higher design strength $\left(f^{\prime} c\right)$ can be optimized by adjusting the binder content. Furthermore, the effects of the binder content on the strength increased with increasing curing time. For example, the mixture with a binder content of $600 \mathrm{~kg} / \mathrm{m}^{3}$ was 1.81 and 2.41 times stronger than the mixture with a binder content of $300 \mathrm{~kg} / \mathrm{m}^{3}$ after 7 and 360 days, respectively.

The modulus of elasticity results are presented in Table 5. These results are consistent with the compressive strength (90 days) results: the AABC had a slightly higher modulus of elasticity (by $4.2 \%$ ) than the OPC (29.14 vs. $27.97 \mathrm{GPa})$. These values are consistent with those reported by Bondar et al. (33) for a concrete based on an Iranian NP $\left(391 \mathrm{~kg} / \mathrm{m}^{3}\right)$ activated with $\mathrm{KOH}$ and $\mathrm{Na}_{2} \mathrm{SiO}_{3}$. These researchers reported values of modulus of elasticity of 32.7 and $29 \mathrm{GPa}$ for the NP-based and reference (OPC) concretes, respectively, after 28 days of curing at 20 $\pm 2{ }^{\circ} \mathrm{C}$. In this work, the ratios of transverse unitary deformation to longitudinal or axial unitary deformation (Poisson's ratio) obtained for the AABC and OPC concretes were 0.16 and 0.19 , respectively (Table 5). These results reflect that the AABC is slightly more rigid than the OPC.

Table 6 lists the measured splitting tensile strengths and flexural strengths (modulus of rupture) of the $\mathrm{AABC}$ and $\mathrm{OPC}$ concretes. In general, the two types of concrete exhibited similar performance, and the properties of both concretes increased with increasing curing time $\left(25^{\circ} \mathrm{C}\right)$. After 360 days of curing, the AABC had a slightly higher splitting tensile strength than the OPC concrete (3.85 vs. $3.23 \mathrm{MPa}$ ), which is consistent with the compressive strength results. As highlighted by Bondar et al. (33), the splitting tensile strength results indicated that an adequate binding force (interface) develops between the aggregates and the paste in the AABC because this property primarily depends on this physical interaction. Figure 6 shows the macro- and micro-interfaces of the AABC and

TABLE 5. Modulus of elasticity (ASTM C469 (59)) of the $\mathrm{AABC}$ and OPC concrete $\left(400 \mathrm{~kg} / \mathrm{m}^{3}\right)$ after 90 days of curing.

\begin{tabular}{lcc}
\hline Mixture & Modulus of elasticity (GPa) & Poisson's ratio (v) \\
\hline AABC & 29.14 & 0.16 \\
OPC & 27.97 & 0.19 \\
\hline
\end{tabular}


Alkali-activated binary concrete based on a natural pozzolan: physical, mechanical and microstructural characterization $\bullet$

TABLE 6. Splitting tensile strengths (ASTM C496 (60)) and flexural strengths (modulus of rupture) (ASTM C293 (61)) of the AABC and OPC concrete $\left(400 \mathrm{~kg} / \mathrm{m}^{3}\right)$.

\begin{tabular}{lcccccccc}
\hline & \multicolumn{3}{c}{ Indirect tensile strength $(\mathbf{M P a})$} & & \multicolumn{3}{c}{ Flexural strength $(\mathbf{M P a})$} \\
\cline { 2 - 4 } \cline { 8 - 9 } Mixture & $\mathbf{2 8}$ days & $\mathbf{9 0}$ days & $\mathbf{3 6 0}$ days & & $\mathbf{2 8}$ days & $\mathbf{9 0}$ days & $\mathbf{3 6 0}$ days \\
\hline AABC & 2.68 & 3.18 & 3.85 & & 4.70 & 5.05 & 5.81 \\
OPC & 2.50 & 2.53 & 3.23 & & 5.94 & 6.62 & 6.67 \\
\hline
\end{tabular}

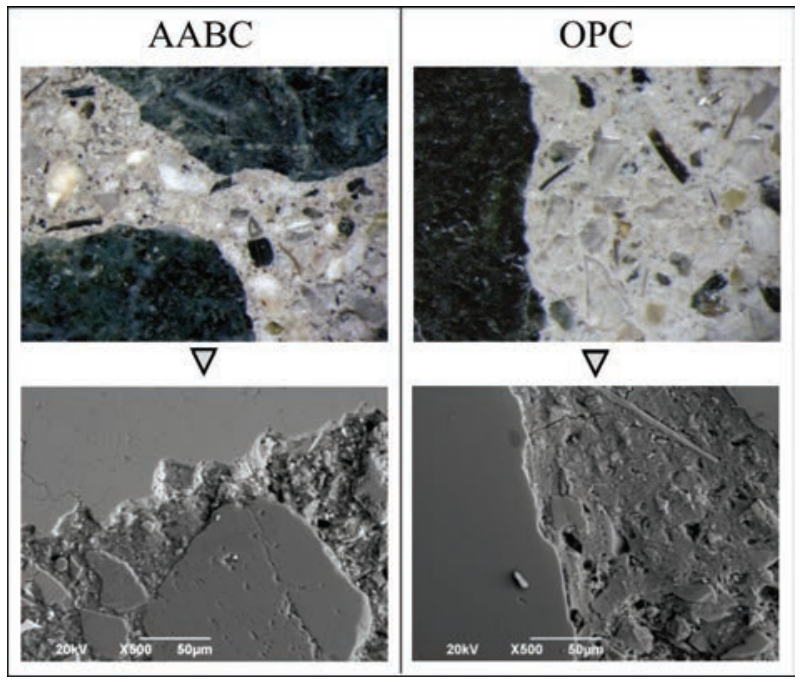

FIGURE 6. Images of the macro-interfaces (optical microscopy) and micro-interfaces (SEM) of the AABC (left) and OPC concrete (right) at 28 days.

OPC concretes after 28 days of curing. Good cohesion (anchoring) between the paste and aggregates and an adequately homogeneous interfacial transition zone were observed for both concretes. The flexural strength of the AABC appeared to be more sensitive to the test conditions used than that of the OPC concrete: the modulus of rupture of the $\mathrm{AABC}$ was $13 \%$ lower than that of the reference concrete (OPC) after 360 days of curing (Table 6).

\subsection{Physical characterization}

The water absorption, density and porosity results for the $\mathrm{AABC}$ and $\mathrm{OPC}$ concretes are presented in Table 7. The concretes clearly exhibited similar physical characteristics. Furthermore, a longer curing time $\left(25^{\circ} \mathrm{C}\right)$ resulted in a slight decrease in the permeable pore volume and/or the densification of the concretes, which is consistent with the observed increases in the mechanical performance of these concretes with increasing curing time (Figure 4). From the results shown in Table 7, it can be deduced that the AABC has a slightly less permeable porous structure (i.e., it absorbs less water) than the OPC concrete.

Similar results were obtained by the mercury porosimetry technique, as shown in Figure 7. In particular,
TABLE 7. Water absorptions, apparent densities and permeable pore volumes (ASTM C642 (62)) of the AABC and $\mathrm{OPC}$ concrete $\left(400 \mathrm{~kg} / \mathrm{m}^{3}\right)$.

\begin{tabular}{lcccc}
\hline Mixture & $\begin{array}{c}\text { Curing age } \\
(\mathbf{d a y s})\end{array}$ & $\begin{array}{c}\text { Absorption } \\
\mathbf{( \% )}\end{array}$ & $\begin{array}{c}\text { Density } \\
\left(\mathbf{k g} / \mathbf{m}^{\mathbf{3}} \mathbf{)}\right.\end{array}$ & $\begin{array}{c}\text { Porosity } \\
(\mathbf{\%})\end{array}$ \\
\hline AABC & 28 & 5.78 & 2636 & 15.18 \\
& 90 & 5.99 & 2637 & 15.12 \\
& 360 & 5.48 & 2656 & 14.29 \\
OPC & 28 & 6.99 & 2632 & 15.82 \\
& 90 & 7.41 & 2647 & 16.80 \\
& 360 & 5.73 & 2662 & 14.52 \\
\hline
\end{tabular}

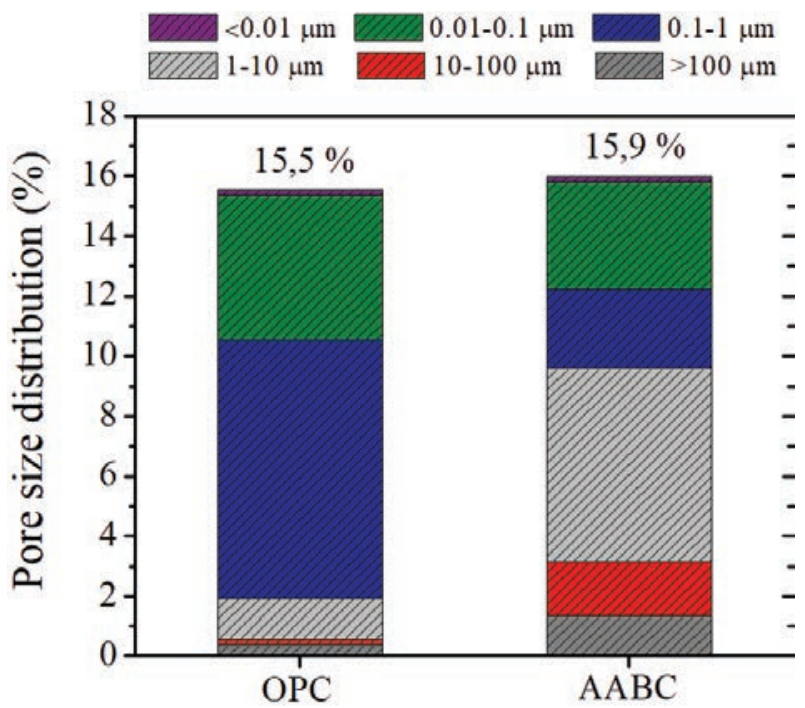

FIGURE 7. Pore size distributions of the AABC and OPC concrete $\left(400 \mathrm{~kg} / \mathrm{m}^{3}\right)$ obtained by mercury porosimetry at 28 days.

the total porosities of the OPC concrete and $\mathrm{AABC}$ measured by this technique were 15.5 and $15.9 \%$, respectively. However, the results also indicated that the OPC concrete had a slightly more refined pore size distribution than the AABC: the majority of its pores $(8.6 \%$ of a total of $15.5 \%)$ were $0.1-1 \mu \mathrm{m}$ in size, whereas the highest fraction of pores in the AABC $(6.45 \%$ of a total of $15.9 \%)$ were $1-10 \mu \mathrm{m}$ in size. The meso-porosity, that is, the fraction of pores smaller than $0.1 \mu \mathrm{m}(100 \mathrm{~nm})$, was $4.99 \%$ for the OPC concrete and $3.76 \%$ for the $\mathrm{AABC}$.

The effects of the binder content (NP-GBFS) on the water absorption, density and porosity of 
TABLE 8. Effects of the binder content $\left(300-600 \mathrm{~kg} / \mathrm{m}^{3}\right.$ NP-GBFS) on the water absorption, density and porosity (ASTM C642) of the AABC.

\begin{tabular}{lcccc}
\hline $\begin{array}{l}\text { NP-GBFS binder } \\
\text { content }\left(\mathbf{k g} / \mathbf{m}^{\mathbf{3}}\right)\end{array}$ & $\begin{array}{c}\text { Curing } \\
\text { age (days) }\end{array}$ & $\begin{array}{c}\text { Absorption } \\
\mathbf{( \% )}\end{array}$ & $\begin{array}{c}\text { Density } \\
\left(\mathbf{k g} / \mathbf{m}^{\mathbf{3}}\right)\end{array}$ & $\begin{array}{c}\text { Porosity } \\
(\mathbf{\%})\end{array}$ \\
\hline 300 & 28 & 8.49 & 2547 & 22.84 \\
& 90 & 8.41 & 2559 & 21.97 \\
& 360 & 8.23 & 2564 & 20.25 \\
450 & 28 & 5.62 & 2648 & 15.34 \\
& 90 & 5.59 & 2665 & 14.92 \\
600 & 360 & 5.38 & 2693 & 14.05 \\
& 28 & 5.33 & 2691 & 13.47 \\
& 90 & 5.24 & 2706 & 13.21 \\
& 360 & 5.08 & 2729 & 12.05 \\
\hline
\end{tabular}

the AABC are presented in Table 8. These results are consistent with the compressive strength results (Figure 5). The permeable pore volume decreased significantly with increasing binder content $\left(300>450>600 \mathrm{~kg} / \mathrm{m}^{3}\right)$. After 28 days of curing, it decreased from $22.84 \%$ to $13.47 \%$ when the binder content was increased from $300 \mathrm{~kg} / \mathrm{m}^{3}$ to $600 \mathrm{~kg} / \mathrm{m}^{3}$, corresponding to a $37 \%$ decrease in the water absorption $\left(8.49 \%\right.$ for $300 \mathrm{~kg} / \mathrm{m}^{3}$ binder vs. $5.33 \%$ for $600 \mathrm{~kg} / \mathrm{m}^{3}$ binder). Likewise, the densification of the matrix increased with increasing curing age for all the $\mathrm{AABC}$ mixtures, which is consistent with the increase in the strength of the mixtures as a function of time (Figure 5).

\subsection{Microstructural characterization of the $A A B C$}

Figure 8 shows the microstructural composition of the AABC (28 days) using a ternary $\mathrm{SiO}_{2}$ $\mathrm{Al}_{2} \mathrm{O}_{3}-\mathrm{CaO}$ diagram obtained from the SEM-EDS data. The results are grouped into regions representing C-S-H gels (high calcium contents) and intermediate calcium-sodium aluminosilicate hydrate (N,C)-A-S-H and C-A-S-H gels ("dreierketten" structure), which are the products of the interactions between the primary N-A-S-H and C-S-H gels that form over time $(64,65)$. The points associated with the C-A-S-H and C-S-H gels, which are rich in $\mathrm{Ca}$, have $\mathrm{Ca} / \mathrm{Si}$ values in the range of $0.7-1.8$. Theoretically, sodium aluminosilicate hydrate (N-A-S-H) gels do not contain $\mathrm{Ca}$, unlike the $(\mathrm{N}, \mathrm{C})-\mathrm{A}-\mathrm{S}-\mathrm{H}$ gels that have $\mathrm{Ca} / \mathrm{Si}$ values in the range of $0-0.4$, which is consistent with the $\mathrm{Ca} / \mathrm{Si}$ ranges reported in the literature (38, 66-70). The EDS elemental mapping results shown in Figure 8 provide a visual representation (colours) of the elementary composition of the AABC. In general, the paste that agglomerates the aggregates is rich in calcium (purple), which confirms the formation of C-S-H, (N,C)-A-S-H and $\mathrm{C}-\mathrm{A}-\mathrm{S}-\mathrm{H}$ gels due to the chemical interactions between the precursor (NP-GBFS) and alkaline activator $(\mathrm{NaOH}+$ waterglass). This compositional analysis of the paste-aggregate interfaces is consistent with the adequate mechanical performance of the $\mathrm{AABC}$.

\section{CONCLUSIONS}

Based on the experimental results, the following conclusions can be drawn:

- The level of slump of the AABC (22 cm) led to a perfect distribution of the aggregates and thus a homogeneous mixture in the hardened state. This level of workability (fluid), along with the high segregation resistance of the $\mathrm{AABC}$ mixture, is considered a technological advantage for applications that require a fluidity or placement efficiency that exceeds that of conventional materials without the need for plasticizing additives.

- The AABC developed strength over time, with compressive strengths of up to $33.2 \mathrm{MPa}$ measured after 360 days of curing $\left(25^{\circ} \mathrm{C}\right)$, which was $10.8 \%$ higher than that of the OPC concrete. Furthermore, the binder content $\left(300-600 \mathrm{~kg} / \mathrm{m}^{3}\right)$ can be adjusted to optimize the curing time $\left(25^{\circ} \mathrm{C}\right)$ to achieve a higher design compressive strength ( $f^{\prime} c 28$ days). Indeed, varying the binder content resulted in compressive strengths of up to 31.5 and $43.4 \mathrm{MPa}$ after 28 and 360 days of curing, respectively. These results, along with the fact that the AABC had a higher modulus of elasticity (29.14 GPa) than the OPC concrete (by $4.2 \%$ ) and exhibited similar flexural and traction behaviour to the reference concrete, indicate that from a mechanical point of view, the $\mathrm{AABC}$ represents a real alternative to OPC in low-to-moderate strength applications $(23 \mathrm{MPa}$ $<f^{\prime} c(28$ days $\left.)<31 \mathrm{MPa}\right)$.

- Consistent with their mechanical performance, the physical properties (water absorption, density and porosity) of the AABC and OPC concretes were similar when prepared under equivalent conditions. In addition, increasing the curing time clearly led to a decrease in the porosity and thus promoted the development of strength in both concretes, regardless of their nature (alkaline (AABC) or hydraulic (OPC)).

- The microstructural analysis of the AABC revealed the presence of $\mathrm{C}-\mathrm{S}-\mathrm{H},(\mathrm{N}, \mathrm{C})-\mathrm{A}-\mathrm{S}-\mathrm{H}$ and C-A-S-H gels, which resulted from the chemical interactions between the precursor (NP-GBFS) and alkaline activator $(\mathrm{NaOH}+$ waterglass). The formation of these reaction products and a coherent paste-aggregate interface is consistent with the observed mechanical performance of the AABC. 

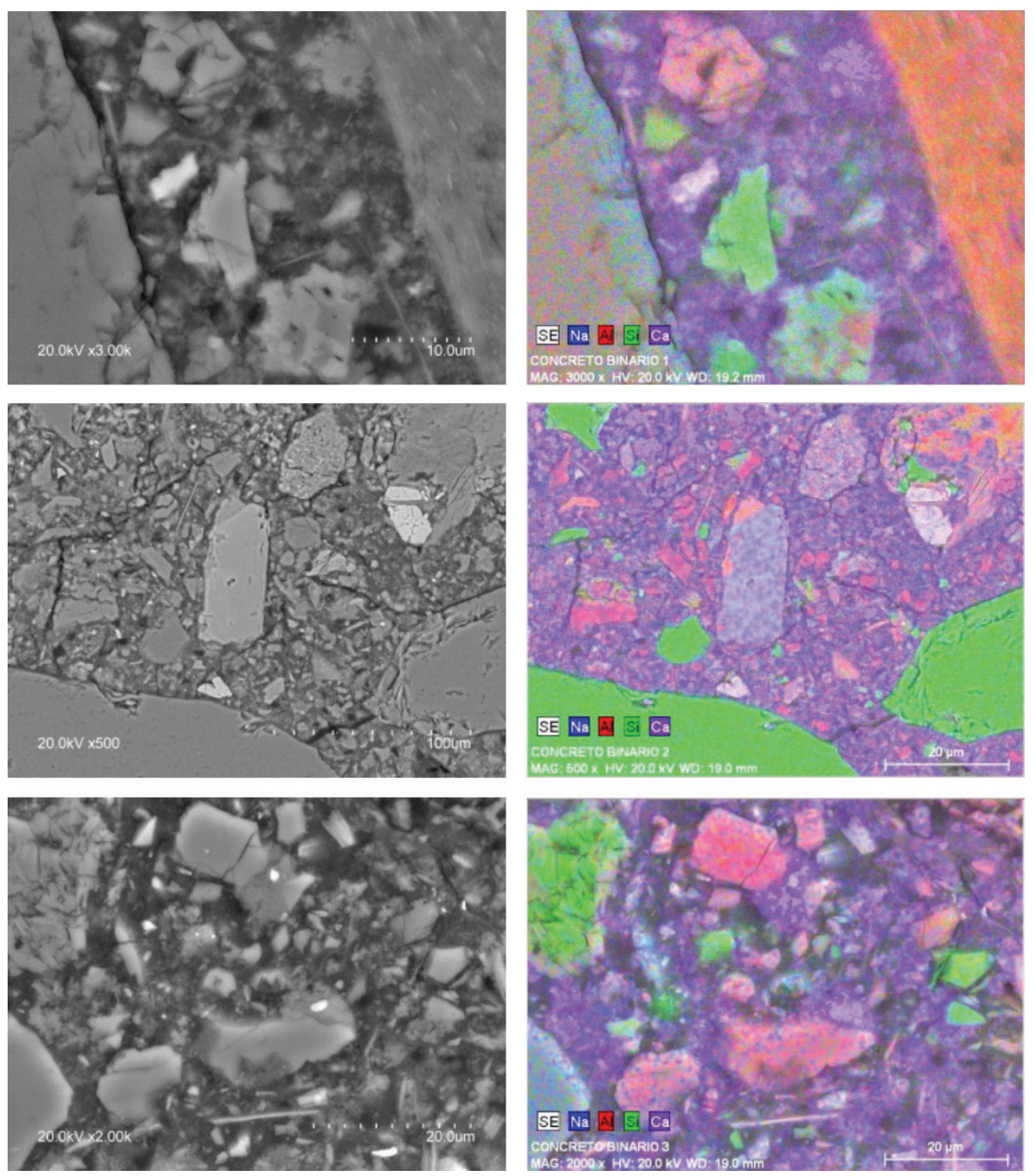

EDS elemental mapping
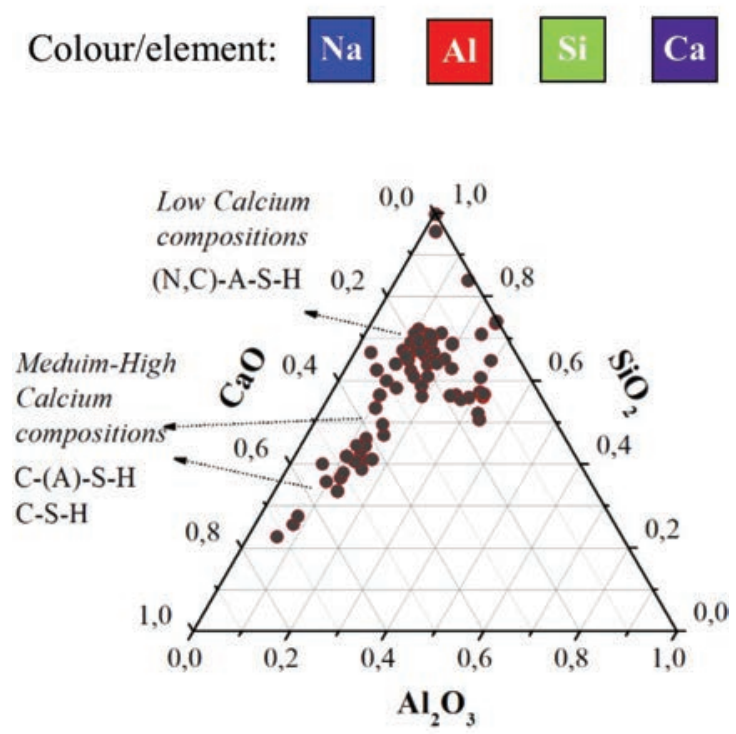

FIGURE 8. Microstructural analysis (EDS elemental mapping) of the AABC (400 kg/m³ 28 days). 
The physical, mechanical and microstructural characterization of the AABC shows that NP deposits in countries rich in volcanic soils, such as Colombia, can be used as readily available raw materials for the industrial-scale production and commercialization of alkaline-activated concretes in the foreseeable future.

\section{ACKNOWLEDGEMENTS}

This research was financed under the "PUZOGEOH" project in call 592-2012 (ColcienciasCementos Argos SA-Universidad del Valle), contract No. 0484-2013. The authors thank the Centro de Excelencia en Nuevos Materiales (CENM) and the Instituto de Ciencias de la Construcción Eduardo Torroja (IETcc-CSIC) in Madrid-Spain for the support received during the development of part of this research. R. Robayo-Salazar thanks Colciencias for the support received in call No. 617 of 2013 for doctorate training in Colombia.

\section{REFERENCES}

1. Davidovits, J. (1994) Properties of Geopolymer Cements. First Int. Conf. Alkaline Cem. Concr. 131-149.

2. Turner, L.K.; Collins, F.G. (2013) Carbon dioxide equivalent $\left(\mathrm{CO}_{2}-\mathrm{e}\right)$ emissions: A comparison between geopolymer and OPC cement concrete. Constr. Build. Mater. 43, 125-130. https://doi.org/10.1016/j.conbuildmat.2013.01.023

3. Provis, J.L. (2016) Alkali-activated materials. Cem. Concr. Res. http://doi.org/10.1016/j.cemconres.2017.02.009

4. Shi, C.; Jiménez, A.F.; Palomo, A. (2011) New cements for the $21^{\text {st }}$ century: The pursuit of an alternative to Portland cement. Cem. Concr. Res. 41, 750-763. https://doi.org/ 10.1016/j.cemconres.2011.03.016

5. Van Deventer, J.S.J.; Provis, J.L. (2014) Alkali-Activated Materials: State-of-the-Art Report, RILEM TC 224-AAM, Springer, (2014). https://doi.org/10.1007/978-94-007-7672-2

6. Bernal, S.A.; Provis, J.L. (2014) Durability of alkali-activated materials: Progress and perspectives. J. Am. Ceram. Soc. 97, 997-1008. https://doi.org/10.1111/jace.12831

7. Palomo, A.; Krivenko, P.; Garcia-Lodeiro, I; Kavalerova, E.; Maltseva, O.; Fernández-Jiménez, A. (2014) A review on alkaline activation: new analytical perspectives. Mater. Construcc. 64, e022. https://doi.org/10.3989/mc.2014.00314

8. Pacheco-Torgal, F.; Labrincha, J.A.; Leonelli, C.; Palomo, A.; Chindaprasirt, P. (2014) Handbook of Alkali-Activated Cements, Mortars and Concretes. Woodhead Publishing Series in Civil and Structural Engineering, (2014). https:// doi.org/10.1016/C2013-0-16511-7

9. Van Deventer, J.S.J.; Provis, J.L.; Duxson, P. (2012) Technical and commercial progress in the adoption of geopolymer cement. Miner. Eng. 29, 89-104. https://doi.org/10.1016/j. mineng.2011.09.009

10. Shoji, S.; Dahlgren, R.; Nanzyo, M. (1993) Terminology, Concepts and Geographic Distribution of Volcanic Ash Soils. Dev. Soil Sci. 21, 1-5. https://doi.org/10.1016/S01662481(08)70262-9

11. Pourkhorshidi, A.R.; Najimi, M.; Parhizkar, T.; Jafarpour F.; Hillemeier, B. (2010) Applicability of the standard specifications of ASTM C618 for evaluation of natural pozzolans. Cem. Concr. Compos. 32, 794-800. https://doi. org/10.1016/j.cemconcomp.2010.08.007

12. Takahashi, T.; Shoji, S. (2002) Distribution and classification of volcanic ash soils. Glob. Environ. Res. 6, 83-97.

13. Lizcano, A.; Herrera, M.C. (2006) Suelos derivados de cenizas volcánicas en Colombia. Rev. Int. Desastres Naturales Accidentes e Infraestructura Civil 6, 167-198.
14. Robayo-Salazar, R.A.; Mejía de Gutiérrez, R. (2018) Natural volcanic pozzolans as an available raw material for alkali-activated materials in the foreseeable future: A review. Constr. Build. Mater. 189, 109-118. https://doi.org/10.1016/j. conbuildmat.2018.08.174

15. Allahverdi, A.; Mehrpour, K.; Kani, E.N. (2008) Investigating the possibility of utilizing pumice-type natural pozzonal in production of geopolymer cement. Ceram. Silikaty. 52, 16-23.

16. Allahverdi, A.; Kani, E.N.; Yazdanipour, M. (2011) Effects of blast furnance slag on natural pozzolan- based geopolymer cement. Ceram. Silikaty. 55, 68-78.

17. Kani, E.N.; Allahverdi, A. (2009) Effect of chemical composition on basic engineering properties of inorganic polymeric binder based on natural pozzolan. Ceram. Silikaty. 53, 195-204.

18. Kani, E.N.; Allahverdi, A.; Provis, J.L. (2017) Calorimetric study of geopolymer binders based on natural pozzolan. J. Therm. Anal. Calorim. 127, 2181-2190. https://doi. org/10.1007/s10973-016-5850-7

19. Kani, E.N.; Allahverdi, A. (2011) Investigating shrinkage changes of natural pozzolan based geopolymer cement paste Iran J. Mater Sci. Eng. 8, 50-60.

20. Kani, E.N.; Allahverdi, A. (2009) Effects of curing time and temperature on strength development of inorganic polymeric binder based on natural pozzolan. J. Mater. Sci. 44, 3088-3097. https://doi.org/10.1007/s10853-009-3411-1

21. Kani, E.N.; Allahverdi, A.; Provis, J.L. (2012) Efflorescence control in geopolymer binders based on natural pozzolan. Cem. Concr. Compos. 34, 25-33. https://doi.org/10.1016/j. cemconcomp.2011.07.007

22. Lemougna, P.N.; Chinje Melo, U.F.; Delplancke, M.P.; Rahier. H. (2014) Influence of the chemical and mineralogical composition on the reactivity of volcanic ashes during alkali activation. Ceram. Int. 40, 811-820. https://doi. org/10.1016/j.ceramint.2013.06.072

23. Lemougna, P.N.; Chinje Melo, U.F.; Delplancke, M.P.; Rahier, H. (2013) Influence of the activating solution composition on the stability and thermo-mechanical properties of inorganic polymers (geopolymers) from volcanic ash. Constr. Build. Mater. 48, 278-286. https://doi.org/10.1016/j. conbuildmat.2013.06.089

24. Lemougna, P.N.; MacKenzie, K.J.D.; Melo, U.F.C. (2011) Synthesis and thermal properties of inorganic polymers (geopolymers) for structural and refractory applications from volcanic ash. Ceram. Int. 37, 3011-3018. https://doi. org/10.1016/j.ceramint.2011.05.002

25. Lemougna, P.N.; MacKenzie, K.J.D.; Jameson, G.N.L.; Rahier, H.; Chinje Melo, U.F. (2013) The role of iron in the formation of inorganic polymers (geopolymers) from volcanic ash: a $57 \mathrm{Fe}$ Mossbauer spectroscopy study. J. Mater. Sci. 48, 5280-5286. https://doi.org/10.1007/s10853-013-7319-4

26. Bondar, D.; Lynsdale, C.J.; Milestone, N.B.; Hassani, N. (2012) Oxygen and chloride permeability of alkali-activated natural pozzolan concrete. ACI Mater. J. 109, 53-61.

27. Bondar, D.; Lynsdale, C.J.; Milestone, N.B.; Hassani, N.; Ramezanianpour, A.A. (2011) Effect of type, form, and dosage of activators on strength of alkali-activated natural pozzolans. Cem. Concr. Compos. 33, 251-260. https://doi. org/10.1016/j.cemconcomp.2010.10.021

28. Bondar, D.; Lynsdale, C.J.; Milestone, N.B.; Hassani, N.; Ramezanianpour, A.A. (2010) Geopolymer cement from alkali-activated natural pozzolans: Effect of addition of minerals. In: $2^{\text {nd }}$ International Conference on Sustainable Construction Materials and Technologies. Italy.

29. Bondar, D.; Lynsdale, C.J.; Milestone, N.B.; Hassani, N.; Ramezanianpour, A.A. (2011) Effect of adding mineral additives to alkali-activated natural pozzolan paste. Constr. Build. Mater. 25, 2906-2910. https://doi.org/10.1016/j. conbuildmat.2010.12.031

30. Bondar, D.; Lynsdale, C.J.; Milestone, N.B. (2012) Simplified Model for Prediction of Compressive Strength of AlkaliActivated Natural Pozzolans. J. Mater. Civ. Eng. 24, 391-400. https://doi.org/10.1061/(ASCE)MT.1943-5533.0000400

31. Bondar, D.; Lynsdale, C.J.; Milestone, N.B.; Hassani, N. (2015) Sulfate Resistance of Alkali Activated Pozzolans. Int. 
J. Concr. Struct. Mater. 9, 145-158. https://doi.org/10.1007/ s40069-014-0093-0

32. Bondar, D.; Lynsdale, C.J.; Milestone, N.B.; Hassani, N.; Ramezanianpour, A.A. (2011) Effect of heat treatment on reactivity-strength of alkali-activated natural pozzolans. Constr. Build. Mater. 25, 4065-4071. https://doi.org/ 10.1016/j.conbuildmat.2011.04.044

33. Bondar, D.; Lynsdale, C.J.; Milestone, N.B.; Hassani, N.; Ramezanianpour, A.A. (2011) Engineering Properties of Alkali Activated Natural Pozzolan Concrete. ACI Mater. J. 108, 64-72.

34. Bondar, D.; Lynsdale, C.J.; Milestone, N.B. (2013) AlkaliActivated Natural Pozzolan Concrete as New Construction Material. ACI Mater. J. 110, 331-338. https://doi.org/ $10.14359 / 51685667$

35. Djobo, J.N.Y.; Tchadjié, L.N.; Tchakoute, H.K.; Kenne, B.B.D.; Elimbi, A.; Njopwouo, D. (2014) Synthesis of geopolymer composites from a mixture of volcanic scoria and metakaolin. J. Asian Ceram. Soc. 2, 387-398. https://doi. org/10.1016/j.jascer.2014.08.003

36. Djobo, J.N.Y.; Elimbi, A.; Dika Manga, J.; Djon Li Ndjock, I.B. (2016) Partial replacement of volcanic ash by bauxite and calcined oyster shell in the synthesis of volcanic ashbased geopolymers. Constr. Build. Mater. 113, 673-681. https://doi.org/10.1016/j.conbuildmat.2016.03.104

37. Djobo, J.N.Y.; Elimbi, A.; Tchakouté, H.K.; Kumar, S. (2016) Mechanical activation of volcanic ash for geopolymer synthesis: effect on reaction kinetics, gel characteristics, physical and mechanical properties. RSC $A d v .6$, 39106-39117. https://doi.org/10.1039/C6RA03667H

38. Djobo, J.N.Y.; Tchakoute, H.K.; Ranjbar, N.; Elimbi, A.; Tchadjie, L.N.; Njopwouo, D.; Biernacki, J. (2016) Gel Composition and Strength Properties of Alkali-Activated Oyster Shell-Volcanic Ash: Effect of Synthesis Conditions. J. Am. Ceram. Soc. 99, 3159-3166. https://doi.org/10.1111/ jace. 14332

39. Djobo, J.N.Y.; Elimbi, A.; Tchakouté, H.K.; Kumar, S. (2016) Mechanical properties and durability of volcanic ash based geopolymer mortars. Constr. Build. Mater. 124, 606-614. https://doi.org/10.1016/j.conbuildmat.2016.07.141

40. Djobo, J.N.Y.; Elimbi, A.; Tchakouté, H.K.; Kumar, S. (2016) Reactivity of volcanic ash in alkaline medium, microstructural and strength characteristics of resulting geopolymers under different synthesis conditions. J. Mater. Sci. 51, 10301-10317. https://doi.org/10.1007/s10853-016-0257-1

41. Tchakouté, H.K.; Elimbi, A.; Mbey, J.A.; Sabouang, C.J.N.; Njopwouo, D. (2012) The effect of adding alumina-oxide to metakaolin and volcanic ash on geopolymers products: A comparative study. Constr. Build. Mater. 35, 960-969. https://doi.org/10.1016/j.conbuildmat.2012.04.023

42. Tchakouté, H.K.; Mbey, J.A.; Elimbi, A.; Kenne Diffo, B.B.; Njopwouo, D. (2013) Synthesis of volcanic ash-based geopolymer mortars by fusion method: Effects of adding metakaolin to fused volcanic ash. Ceram. Int. 39, 1613-1621. https://doi.org/10.1016/j.ceramint.2012.08.003

43. Tchakoute, H.K.; Elimbi, A.; Yanne, E.; Djangang, C.N. (2013) Utilization of volcanic ashes for the production of geopolymers cured at ambient temperature. Cem. Concr. Compos. 38, 75-81. https://doi.org/10.1016/j.cemconcomp. 2013.03.010

44. Tchakoute, H.K.; Elimbi, A.; Kenne Diffo, B.B.; Mbey, J.A.; Njopwouo, D (2013) Synthesis of geopolymers from volcanic ash via the alkaline fusion method: Effect of $\mathrm{Al}_{2} \mathrm{O}_{3} /$ $\mathrm{Na}_{2} \mathrm{O}$ molar ratio of soda-volcanic ash. Ceram. Int. 39, 269-276. https://doi.org/10.1016/j.ceramint.2012.06.021

45. Robayo-Salazar, R.A.; Mejía de Gutiérrez, R.; Gordillo, M. (2016) Natural pozzolan-and granulated blast furnace slag-based binary geopolymers. Mater. Construcc. 66 [321], e077. https://doi.org/10.3989/mc.2016.03615

46. Jafari Nadoushan, M.; Ramezanianpour, A.A. (2016) The effect of type and concentration of activators on flowability and compressive strength of natural pozzolan and slag-based geopolymers. Constr. Build. Mater. 111, 337-347. https://doi. org/10.1016/j.conbuildmat.2016.02.086

47. Robayo-Salazar, R.A.; Mejia de Gutierrez, R.; Puertas, F. (2017) Study of synergy between a natural volcanic pozzolan and a granulated blast furnace slag in the production of geopolymeric pastes and mortars. Constr. Build. Mater. 157, 151-160. https://doi.org/10.1016/j.conbuildmat. 2017.09.092

48. Najimi, M.; Ghafoori, N.; Sharbaf, M. (2018) Alkaliactivated natural pozzolan/slag mortars: A parametric study. Constr. Build. Mater. 164, 625-643. https://doi. org/10.1016/j.conbuildmat.2017.12.222

49. Fernández-Jiménez, A; Puertas, F; Sobrados, I; Sanz, J. (2003) Structure of Calcium Silicate Hydrates Formed in Alkaline-Activated Slag: Influence of the Type of Alkaline Activator. J. Am. Ceram. Soc. 86, 1389-1394. https://doi. org/10.1111/j.1151-2916.2003.tb03481.x

50. Puertas, F.; Palacios, M.; Manzano, H.; Dolado, J.S.; Rico, A.; Rodríguez, J. (2011) A model for the C-A-S-H gel formed in alkali-activated slag cements. J. Eur. Ceram. Soc. 31, 2043-2056. https://doi.org/10.1016/j.jeurceramsoc. 2011.04.036

51. Puertas, F. (1995) Cementos de escorias activadas alcalinamente: Situación actual y perspectivas de futuro. Mater. Construcc. 45, 53-64. https://doi.org/10.3989/mc.1995.v45. i2 239.553

52. Haddad, R.H.; Alshbuol, O. (2016) Production of geopolymer concrete using natural pozzolan: A parametric study. Constr. Build. Mater. 114, 699-707. https://doi.org/10.1016/j. conbuildmat.2016.04.011

53. Najimi, M. (2016) Alkali-Activated Natural Pozzolan/ Slag Binder for Sustainable Concrete. UNLV Theses, Dissertations, Professional Papers, and Capstones. 2885. https://digitalscholarship.unlv.edu/thesesdissertations/ 2885/

54. ASTM International (2017) ASTM C1157/C1157M-17, Standard Performance Specification for Hydraulic Cement.

55. ACI Committee 211 (2002) Standard practice for selecting proportions for normal, heavyweight, and mass concrete (ACI 211.1-91)

56. Fuller, W.B.; Thomson, S.E. (1907) The Laws of Proportioning Concrete. Trans. Am. Soc. Civ. Eng. ASCE Libr LIX, 67-143.

57. ASTM International (2015) ASTM C143/C143M-15a, Standard Test Method for Slump of Hydraulic-Cement Concrete.

58. ASTM International (2018) ASTM C39/C39M-18, Standard Test Method for Compressive Strength of Cylindrical Concrete Specimens.

59. ASTM International (2014) ASTM C469/C469M-14, Standard Test Method for Static Modulus of Elasticity and Poisson's Ratio of Concrete in Compression.

60. ASTM International (2017) ASTM C496/C496M-17, Standard Test Method for Splitting Tensile Strength of Cylindrical Concrete Specimens

61. ASTM International (2016) ASTM C293/C293M-16, Standard Test Method for Flexural Strength of Concrete (Using Simple Beam with Center-Point Loading).

62. ASTM International (2013) ASTM C642-13, Standard Test Method for Density, Absorption, and Voids in Hardened Concrete.

63. Ibrahim, M.; Megat Johari, M.A.; Rahman, M.K.; Maslehuddin, M. (2017) Effect of alkaline activators and binder content on the properties of natural pozzolan-based alkali activated concrete. Constr. Build. Mater. 147, 648-660. https://doi.org/10.1016/j.conbuildmat.2017.04.163.

64. Garcia-Lodeiro, I.; Palomo, A.; Fernández-Jiménez, A.; MacPhee, D.E. (2011) Compatibility studies between N-A$\mathrm{S}-\mathrm{H}$ and C-A-S-H gels. Study in the ternary diagram $\mathrm{Na}_{2} \mathrm{O}-$ $\mathrm{CaO}-\mathrm{Al}_{2} \mathrm{O}_{3}-\mathrm{SiO}_{2}-\mathrm{H}_{2} \mathrm{O}$. Cem. Concr. Res. 41, 923-931. https://doi.org/10.1016/j.cemconres.2011.05.006

65. Garcia-Lodeiro, I.; Donatello, S.; Fernández-Jiménez, A.; Palomo, A. (2016) Hydration of hybrid alkaline cement containing a very large proportion of fly ash: A descriptive model. Materials 9,605. https://doi.org/10.3390/ma 9070605

66. Ortega, E.A.; Cheeseman, C.; Knight, J.; Loizidou, M. (2000) Properties of alkali-activated clinoptilolite. Cem. Concr. Res. 30, 1641-1646. https://doi.org/10.1016/S00088846(00)00331-8 
67. García Lodeiro, I.; Macphee, D.E.; Palomo, A.; FernándezJiménez, A. (2009) Effect of alkalis on fresh C-S-H gels. FTIR analysis. Cem. Concr. Res. 39, 147-153. https://doi. org/10.1016/j.cemconres.2009.01.003

68. García-Lodeiro, I.; Fernández-Jiménez, A.; Palomo, A. (2013) Variation in hybrid cements over time. Alkaline activation of fly ash-Portland cement blends. Cem. Concr. Res. 52, 112-122. https://doi.org/10.1016/j.cemconres.2013. 03.022
69. Gebregziabiher, B.S.; Thomas, R.J.; Peethamparan, S. (2016) Temperature and activator effect on early-age reaction kinetics of alkali-activated slag binders. Constr: Build. Mater. 113, 783-793. https://doi.org/10.1016/j. conbuildmat.2016.03.098

70. Sánchez-Herrero, M.J.; Fernández-Jiménez, A.; Palomo, A.; Klein, L. (2016) Alkaline Hydration of $\mathrm{C}_{2} \mathrm{~S}$ and $\mathrm{C}_{3} \mathrm{~S}$. J. Am. Ceram. Soc. 99, 604-611. https://doi.org/10.1111/ jace. 13985 